\title{
The Effect of Coach Competence, Participant Motivation and Curriculum on the Effectiveness of the Export Coaching Program
}

\author{
Abdillah Sani \\ Indonesia Export Training Center Directorate General of National Export Development, Miistry of Trade \\ Email: abdillahsani@yahoo.com
}

ARTICLE INFO

Keyword:

Export;

Coaching Program;

Effectiveness.

Kata Kunci:

Ekspor;

Program Pelatihan;

Affectivity

\begin{abstract}
The Results of the Implementation of the Export Coaching Program by the Indonesian Export Training Center (IETC) in 2018 in Tangerang, Bandung and Surabaya, discussed about 75 participants, of which only 32 were approved as new exporters. Although this amount is $100 \%$ of the target set, but seen from the overall participants, the achievement was only $43 \%$. This result is not commensurate with aspects of time, effort and cost. Therefore, through this research we want to know what factors must be questioned so that this program is more effective. The 3 variables translated were trainer's competence, participant motivation and curriculum. Data collection was carried out through literature study, questionnaire collection and interviews. Data analysis uses multiple regression methods, which produce facts, and have a significant effect, with the curriculum as the variable with the strongest influence. Based on these findings, it is recommended that the curriculum be more complete, in addition to increasing the competency of trainers and participant motivation.
\end{abstract}

Abstrak: Hasil Implementasi Program Pelatihan Ekspor oleh Pusat Pendidikan dan Pelatihan Ekspor Indonesia (PPEI) pada tahun 2018 di Tangerang, Bandung, dan Surabaya, membahas 75 peserta, yang hanya 32 yang disetujui sebagai eksportir baru. Meskipun jumlah ini adalah 100\% dari target yang ditetapkan tetapi dilihat dari keseluruhan peserta, pencapaiannya hanya 43\%. Hasil ini tidak sepadan dengan aspek waktu, tenaga dan biaya. Oleh karena itu, melalui penelitian ini, kami ingin mengetahui faktor apa yang harus dipertanyakan sehingga program ini lebih efektif. 3 variabel yang diterjemahkan adalah Competence pelatih, Motivation peserta, dan Curriculum. Pengumpulan data dilakukan melalui studi literatur, pengumpulan kuesioner, dan wawancara. Analisis data menggunakan metode regresi berganda, yang menghasilkan fakta, dan memiliki pengaruh signifikan, dengan Curriculum sebagai variabel dengan pengaruh terkuat. Berdasarkan temuan ini, direkomendasikan agar Curriculum menjadi lebih lengkap, di samping meningkatkan Competence pelatih dan Motivation peserta.

Article History： Received; 2020-01-16, Revised; 2020-02-10, Accepted; 2020-02-20

\section{INTRODUCTION}

Human resources (HR) have a strategic role for an organization in achieving sustainability goals and objectives. Likewise, companies that want to increase sales from the domestic market to the international market need to equip themselves with human resources who have competencies in accordance with those prepared for business people on the global scene. In their publication titled innovation, internalization, and entrepreneurship: New Research Business Perspectives, Yu and SI (2012, in Wawan Dewanto, et al, 2019) stated as two examples of internationalization research studies, small and micro and medium enterprises (SMEs), have 
been increasing. This is one proof that SMEs have the potential and potential to internationalize business. Therefore, to support the success of the business internationalization strategy, SMEs must support their role in managing companies, challenging to take risks (risk takers) and being responsible for innovation, carefully calculating financing and improving in transforming products in international markets.

In connection with the development of human resources, the role of Education and Training Institutions (ETI) is becoming increasingly important. Competition in an era of increasingly strong globalization requires training institutions to continue to improve various aspects of education, management, program innovation, marketing to finance. The Indonesian Export Training Center (IETC) which was formed by the Government of Indonesia in collaboration with JICA Japan in 1990 and up to now is active in carrying out training activities for Small and Medium Enterprises (SMEs), is also not free from this requirement. The number of export training activities carried out by IETC is 130 batches per year plus the Export Coaching Program all require continuous quality improvement.

In the Export Coaching Program, a coach plays an important role in providing Coaching to participants, following a series of programs. This means that the coach needs to complete his competence, including all the coaching program activities. The coach gives an influence on the participants 'motivation in terms of loyalty, productivity improvement, and commitment and training participants' performance.

Jean Côté and Wade Gilbert (2009), using the same method in his research on the influence of coach expertise, athlete attributes and conceptual models of training on the effectiveness of mentoring for athletes stated that these three variables are supporting components of training effectiveness. Another similar study was conducted by Nanny Rodjinandari et al (2016), about the Competency of Local Tour Guide Coaching as a Developer of People that discussed the competencies of Local Guide Guides and concluded that mentally mentoring for local tour guides was very beneficial for improve their competence. The third research that used competency, motivation and curriculum variables to measure the effectiveness of Coaching was conducted by Ninuk Purwaningsih, Titi Mawasti and Yudhistira Saraswati (2017), on Analysis of Coaching Needs and Competency Companion of Herbal Medicine Industry Business Players.

Meanwhile, the program curriculum according to Law No. 20 of 2003 concerning the National Education System is a set of plans and arrangements relating to the objectives, content, teaching materials and methods used as a guide in organizing learning activities in achieving national education goals. The curriculum is the intention and hope set forth in the form of plans and educational programs implemented by educators (Nana Sudjana, 2005).

From the description above, it appears that a very important relationship between the various elements involved in training activities, so that in the Export Coaching Program it is also important to study whether coach competency, participant motivation and curriculum have a significant influence on the level of effectiveness of the program. The ultimate goal is to seek input for various parties concerned so that the implementation of the export coaching program can become more optimal in encouraging increased national exports through increasing the competence of SMEs in penetrating the global market.

Since 2010 the Export Coaching Program has been run by IETC in various provinces and major cities in Indonesia and every year this program is held in 3 (three) batches in 3 (three) regions, each consisting of 25 participants. In 2018 this activity was carried out in Bandung, Surabaya and Tangerang, with a total of 75 participants. From the implementation of the Export Coaching Program for approximately 10 years, it is known that the final results achieved were still not in accordance with the large number of participants, even though the target of the new exporters being set could be achieved.

This Export Coaching Program applies the one year full mentoring method. The coaching method was chosen because it was considered more effective than the usual training method, as Rosinsky (2013, in Norasmah Othman and Swee Yee Chia, 2014) said, that Coaching refers to the skill of helping others to unleash their potential to achieve their desired goals. Meanwhile according to Sir John Whitmore (2009), Coaching opens a person's potential to maximize their 
own performance and helps them learn more than they teach, because in coaching, there is a series of dialogues between Coach and trainees (Starr, 2008). Coaching also refers to a systematic process to improve one's abilities and performance in teaching and learning by providing guidance and feedback (Redshaw, 2000). In addition, Coaching allows individuals to obtain the knowledge and skills they need to develop professional practice and work more effectively (Stone, 1999), in accordance with the direction of the Trade Fascilitation Office, Canada (2010) as a partner of IETC's cooperation which states that exports The coaching program has 3 stages of goals to be achieved: "The three stages of export preparation help the exporter to learn about exporting step-by-step. The exporter can focus on each step until they have accomplished the objectives for that stage."

Many models can be used in Coaching, some of which are transpersonal models, cultural transformational tools, change curves, transactional analysis, and appreciative inquiry models (Berny Gomulya, et al, 2019), but the coaching model that is considered appropriate for the Export Coaching Program is the GROW model. GROW according to Berny Gomulya (2015) is an abbreviation of Goal (goal), Reality (reality), Options (choice) and What Next or Will (hope), whose basic structure was first put forward by Sir John Whitemore. The basic idea of the GROW model is in conformity with the objectives of organizing the Export Coaching Program by IETC, which is to encourage the birth of new exporters based on the real conditions that exist in each participating SME, referring to the TFO directives. Coaching model is considered the most suitable for fostering export SMEs, because it can further enhance motivation, decision making, relationships between participants and between participants and coaches.

The choice of coaching as a model for coaching SMEs also refers to the results of a survey conducted by the Chartered Institute of Personnel and Development, which found that $99 \%$ of 500 respondents agreed that 'Coaching can produce tangible benefits, both for individuals and organizations. The survey results also showed that $96 \%$ of respondents agreed that coaching was an effective way. to promote learning in organizations (NHS, 2005, in Norasmah Othman1 and Swee Yee Chia, 2014). In research on the analysis of the influence of coach competency, participant motivation and curriculum on the effectiveness of this export Coaching program the variables studied are:

\section{Competency Coach}

Boyatzis (in Endang Dhamayantie and Rizky Fauzan, 2017) defines competence as a capability or capability. According to Kaur \& Bains (2013), competence is the amount of experience, knowledge, skills and attitudes needed during life for the effectiveness of performance on a task or job. Spencer \& Spencer (1993: 9) defines competence as a fundamental characteristic of each individual that is associated with effective and / or superior performance criteria. Meanwhile Baum (in Endang Dhamayantie and Rizky Fauzan, et al, 2017) explained that competence is an individual character such as the knowledge, skills and abilities needed to do certain jobs.

The coach or companion must have high competence because the coach has a different role from the "teaching pattern". Coaching, more role as "Friendship with the companion" who is ready to help difficulties. The coach is not a supervisor who looks for the faults he is assisting, however, rather acts as a relationship that is ready to assist difficulties in the development of the company. The main role of assistants according to Nanny Rodjinandari and Bambang Supriadi (2016)) there are four things, namely: (a) as a coordinator whose role is to coordinate the programs and materials needed to improve the performance of the person being assisted; (b) as a consultant who must have the ability to specialize in materials, learning methodologies, and development; (c) as a group leader (group leader); and finally (d) as an evaluator who will evaluate the implementation of learning, and be able to help identify problems faced by the person being accompanied.

The responsibilities of a Coach according to TFO Canada are: Preparation, Building the relationship, Communication, setting long-term goals, Skills and confidence development, overcoming challenges, Networking and Changing patterns and behaviors, so the measurement 
of a Coach's competency according to TFO is: Accessible, Good listener, Organized, Guidance, Supportive, Inspired, Provides referrals, Options and Action-oriented (TFO Canada, 2010).

\section{Motivation}

In training activities, including in the Export Coaching Program, the success of the program will only be achieved if participants are earnest and have high motivation, both to go through all stages of the program and to pursue their aspirations to become exporters. Motivation is a psychological process that gives purpose and direction to behavior. Motivation at work is one of the variables that greatly determines performance, considering the function of motivation is as a direction, in which people will ambitious and can take action and make efforts to achieve something.

Measurement of motivation of participants of the Export Coaching Program according to TFO are: making preparations, building relationships, carrying out communication, setting longterm goals, developing skills and confidence (Skills and confidence) confidence development), facing challenges (Overcoming challenges) and building networks (Networking).

\section{Curriculum}

The curriculum is a set of plans and arrangements regarding the objectives, content, and learning materials as well as the methods used to guide the implementation of learning activities to achieve certain educational goals, as stated in Law Number 20 Year 2003 concerning the National Education System (SISDIKNAS).

\section{Effectiveness}

Effectiveness according to the Big Indonesian Dictionary is the usability, activeness, and suitability in an activity between a person carrying out a task and the objectives to be achieved, whereas according to TFO the effectiveness of the Export Coaching Program is: How to integrate into current export training topics, meaning this program will be considered effective if the results are in accordance with the objectives, namely giving birth to new exporters. In relation to the structure of the GROW model, research on the effectiveness of the Export Coaching Program is due to disturbing conditions, namely (Erni Julia KOK, 2015):

1. Performance gap issues. Not achieving the maximum results from the implementation of the program, given the number of participants as many as 75 people, it turns out that in 2018 there were only 32 people who managed to become new exporters. This means that the effectiveness of the program is only $43 \%$, although the target number for the year of 32 people was indeed obtained (100\%), but seen from the total participants, these results have not reached half.

2. Kill Deficiencies. There is a limited competency of participants in the Export Coaching Program to export and there are differences in the conditions of each participant as a whole.

3. Increased productivity. Participants who undergo the coaching process are expected to understand how to prepare and undergo activities in the context of exports, so that their performance is considered optimal if there is an increase in the ability to find solutions to the problems they face.

4. Prepare staff. In the implementation of the Export Coaching Program, the ability of coaches to provide effective Coaching in accordance with the established curriculum must also be tested, so that its routine implementation every year will create coaches who have increasingly qualified competencies.

\section{Hypothesis Formulation}

In accordance with the literature above, the hypothesis in this study is:

1) There is an influence of the trainer competency variable on the implementation of the Export Coaching Program.

2) There is an effect of the Participant Commitment variable on the Export Coaching Program. 
3) There is an effect of the curriculum variable on the implementation Export Coaching Program.

4) There is an influence of the trainer competency variable, participant commitment and curriculum on the Export Coaching Program.

\section{RESEARCH METHOD}

In this study there are three independent variables, namely coach competency (X1), participant motivation (X2) and curriculum (X3) which will be tested for their effect on the effectiveness variable $(\mathrm{Y})$ as illustrated below, in figure 1 following:

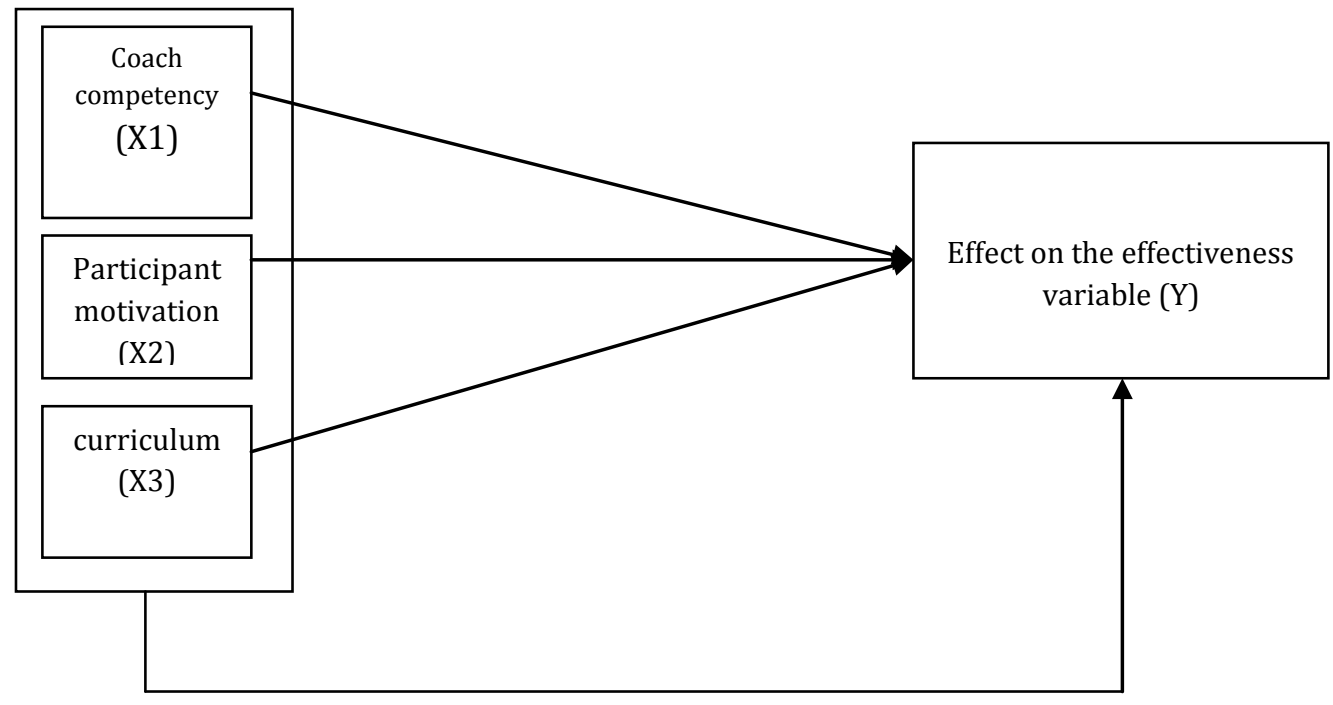

Figure 1

Research Frramework

Source: (Sugiyono, 2017)

\section{Object of research}

The object of this research is the influence of coach competency, participant motivation and curriculum on the Effectiveness of the Export Coaching Program.

a. Population

The population in this study was the participants of the Export Coaching Program carried out in the 2018 fiscal year in West Java Province (Bandung), East Java Province (Surabaya) and Tangerang Regency, with 25 participants in each generation and the total number of participants in each these three regions are 75 people. The reasons for population selection are as follows:

1) The implementation of the Export Coaching Program in 2018 uses a more refined curriculum, in which activities are added and activities will be eliminated, with the hope that there will be a significant increase in effectiveness.

2) In organizing in 2018 the number of participants was reduced to only 25 people per class, down from the original number of 30 people.

3) The implementation of the Export Coaching Program in 2018 uses a curriculum that has been improved for the second time, since the implementation began in 2010 and the first curriculum improvement was carried out in 2015.

b. Sample

To obtain research data, a questionnaire was distributed to all participants (75 people), where only 40 people filled out and returned the questionnaire sheets. The forty respondents were then selected to be the population using the saturated sampling method, where all members of the population were then used as samples (Sugiyono, 2014: 85). 


\section{A. Test Validity}

\section{RESULT AND DICUSSION}

Validity test is used to show the validity of the research instrument means that the instrument can be used to measure what should be measured in this study using the product moment correlation coefficient if the result exceeds the degree of freedom $(\mathrm{dk})=\mathrm{n}-2=40-2=$ 38 , so rtable $=0.2638$ (rcount $>0.2638$ ) or a significant value $<0.05$. The value of the product moment correlation coefficient can be seen from the results of data processing in table 1 as follows:

Table 1

Validity Test X1 (Competency)

\begin{tabular}{|c|c|c|c|c|c|c|c|}
\hline \multicolumn{8}{|c|}{ Correlations } \\
\hline & & item_1 & item_2 & item_3 & item_4 & item_5 & score total \\
\hline \multirow[t]{3}{*}{ item_1 } & Pearson Correlation & 1 & ,768 & $810^{* *}$ &, $783^{* *}$ &, $859^{* *}$ & $910^{* *}$ \\
\hline & Sig. (2-tailed) & & ,000 & ,000 & ,000 & 000 & ,000 \\
\hline & $\mathrm{N}$ & 40 & 40 & 40 & 40 & 40 & 40 \\
\hline \multirow[t]{3}{*}{ item_2 } & Pearson Correlation &, $768^{* *}$ & 1 &, $957^{* *}$ &, $785^{* *}$ &, $734^{* *}$ &, $921^{* *}$ \\
\hline & Sig. (2-tailed) & ,000 & & 000 & ,000 & ,000 & ,000 \\
\hline & $\mathrm{N}$ & 40 & 40 & 40 & 40 & 40 & 40 \\
\hline \multirow[t]{3}{*}{ item_3 } & Pearson Correlation &, $810^{* *}$ & ,957** & 1 & ,808** &, $777^{* *}$ &, $944^{* *}$ \\
\hline & Sig. (2-tailed) & 000 & ,000 & & ,000 & ,000 & ,000 \\
\hline & $\mathrm{N}$ & 40 & 40 & 40 & 40 & 40 & 40 \\
\hline \multirow[t]{3}{*}{ item_4 } & Pearson Correlation & ,783** & ,785** & ,808* & 1 &, $926^{* *}$ &, $927^{* *}$ \\
\hline & Sig. (2-tailed) & 000 & ,000 & 000 & & ,000 & ,000 \\
\hline & $\mathrm{N}$ & 40 & 40 & 40 & 40 & 40 & 40 \\
\hline \multirow[t]{3}{*}{ item_5 } & Pearson Correlation &, $859^{* *}$ &, $734^{* *}$ &, $777^{* *}$ &, $926^{* *}$ & 1 &, $924^{* *}$ \\
\hline & Sig. (2-tailed) & ,000 & ,000 & ,000 & ,000 & & ,000 \\
\hline & $\mathrm{N}$ & 40 & 40 & 40 & 40 & 40 & 40 \\
\hline \multirow[t]{3}{*}{ skor_total } & Pearson Correlation & ,910** & ,921** &, $944^{* *}$ &, $927^{* *}$ & ,924** & 1 \\
\hline & Sig. (2-tailed) & 000 & 000 &, 000 & ,000 & 000 & \\
\hline & $\mathrm{N}$ & 40 & 40 & 40 & 40 & 40 & 40 \\
\hline
\end{tabular}

Source: Source: SPSS 24 output, processed data

Table 2

Competency Validity Test Result

\begin{tabular}{cccc}
\hline Questioner & R count & R table & Notes \\
\hline Question 1 & 0,910 & 0,2638 & Valid \\
Question 2 & 0,921 & 0,2638 & Valid \\
Question 3 & 0,944 & 0,2638 & Valid \\
Question 4 & 0,927 & 0,2638 & Valid \\
Question 5 & 0,924 & 0,2638 & Valid \\
\hline
\end{tabular}

Source: SPSS 24 output, processed data

Based on the table 2 above, all items about Competency questions where $\mathrm{R}$ count is greater than $\mathrm{R}$ table then the questions on the Competency variable are declared valid.

a. Validity Test X2 (Motivation)

Table 3

Motivation Validity Test Result (X2)

\begin{tabular}{cccc}
\hline Questioner & R count & R table & Notes \\
\hline Question 1 & 0,946 & 0,2638 & Valid \\
Question 2 & 0,960 & 0,2638 & Valid \\
Question 3 & 0,927 & 0,2638 & Valid \\
Question 4 & 0,947 & 0,2638 & Valid \\
Question 5 & 0,952 & 0,2638 & Valid \\
\hline
\end{tabular}

Source: SPSS 24 output, processed data 
b. Validity test was also carried out for the curriculum variable (X3).

Table 5

Curriculum Validity Test (X3)

\begin{tabular}{|c|c|c|c|c|c|c|c|}
\hline \multirow{2}{*}{\multicolumn{8}{|c|}{ Correlations }} \\
\hline & & & & & & & \\
\hline & & item_1 & item_2 & item_3 & item_4 & item_5 & skor_total \\
\hline item_1 & Pearson Correlation & 1 & ,898** & ,804** & ,896** &, $827^{* *}$ & ,938** \\
\hline & Sig. (2-tailed) & & 000 & ,000 & ,000 & 000 & 000 \\
\hline & $\mathrm{N}$ & 40 & 40 & 40 & 40 & 40 & 40 \\
\hline item_2 & Pearson Correlation & ,898** & 1 &, $903^{* *}$ &, $883^{* *}$ &, $871^{* *}$ &, $967^{* *}$ \\
\hline & Sig. (2-tailed) & ,000 & & ,000 & ,000 & ,000 & ,000 \\
\hline & $\mathrm{N}$ & 40 & 40 & 40 & 40 & 40 & 40 \\
\hline item_3 & Pearson Correlation &, $804^{* *}$ &, $903^{* *}$ & 1 & $876^{* *}$ &, $778^{* *}$ & $926^{* *}$ \\
\hline & Sig. (2-tailed) & ,000 & ,000 & & ,000 &, 000 & ,000 \\
\hline & $\mathrm{N}$ & 40 & 40 & 40 & 40 & 40 & 40 \\
\hline item_4 & Pearson Correlation & ,896** &, $883^{* *}$ &, $876^{* *}$ & 1 &, $871^{* *}$ & $960^{* *}$ \\
\hline & Sig. (2-tailed) & 000 & ,000 & ,000 & &, 000 & ,000 \\
\hline & $\mathrm{N}$ & 40 & 40 & 40 & 40 & 40 & 40 \\
\hline item_5 & Pearson Correlation &, $827^{* *}$ &, $871^{* *}$ &, $778^{* *}$ & $871^{* *}$ & 1 &, $922^{* *}$ \\
\hline & Sig. (2-tailed) & ,000 & ,000 & ,000 & ,000 & & ,000 \\
\hline & $\mathrm{N}$ & 40 & 40 & 40 & 40 & 40 & 40 \\
\hline skor_total & Pearson Correlation & ,938** &, $967^{* *}$ &, $926^{* *}$ &, $960^{* *}$ &, $922^{* *}$ & 1 \\
\hline & Sig. (2-tailed) & ,000 & ,000 & ,000 & ,000 & ,000 & \\
\hline & $\mathrm{N}$ & 40 & 40 & 40 & 40 & 40 & 40 \\
\hline **. Correlat & on is significant at the & 01 level & cailed). & & & & \\
\hline Source: SPSS & 4 output, processed data & & & & & & \\
\hline & & Curri & lum Vali & $\begin{array}{l}6 \\
\text { Test Re }\end{array}$ & It (X3 & & \\
\hline & Questioner & & count & & ble & & tes \\
\hline Question 1 & & 0,93 & & 0,2638 & & Valid & \\
\hline Question 2 & & 0,96 & & 0,2638 & & Valid & \\
\hline Question 3 & & 0,92 & & 0,2638 & & Valid & \\
\hline Question 4 & & 0,96 & & 0,2638 & & Valid & \\
\hline Question 5 & & 0,92 & & 0,2638 & & Valid & \\
\hline
\end{tabular}

Source: SPSS 24 output, processed data

Based on the above table 5 and table 6, it is known that the R count is greater than the $R$ table, so the questions on the Curriculum variables can be declared valid, as shown in the curriculum validity test table above.

c. Test Validity of Effectiveness (Y)

Table 7

Test results for effectiveness validity

\begin{tabular}{lllll}
\hline & Questioner & R count & R table & Notes \\
\hline Question 1 & 0,926 & 0,2638 & Valid & \\
Question 2 & 0,942 & 0,2638 & Valid & \\
Question 3 & 0,959 & 0,2638 & Valid & \\
Question 4 & 0,927 & 0,2638 & Valid & \\
Question 5 & 0,936 & 0,2638 & Valid &
\end{tabular}

Source: SPSS 24 output, processed data 
Based on the table, all items about Effectiveness questions where $r$ count is greater than rtable, then questions on the Effectiveness variable can be declared valid.

\section{B. Reliability Test}

Reliability test is an index that shows the extent to which a tool can be trusted or relied on. This means that it shows the extent to which the measurement results remain consistent when measurements are made twice or more. In a group of statement items are stated to be reliable if the Cronbach alpha coefficient number (á)>0.6. The reliability test in this study was conducted on 40 respondents with a total of 5 questions each for the Competency questionnaire item, 5 items for the Motivation questionnaire, 5 items for the Curriculum questionnaire and 5 questions for the Effectiveness questionnaire, The following are the results of the reliability test of 40 respondents:

Table 8

Reliability Competence Test (X1)

\begin{tabular}{ll}
\hline Reliability Statistics & \\
Cronbach's Alpha & N of Items \\
\hline, 958 & 5 \\
\hline
\end{tabular}

Source: SPSS 24 output, processed data

In the table 8 above the reliability test can be seen that the Cronbach alpha value for the competency variable is 0.958 , this shows that the question of the Competency style variable is Reliable because the Cronbach alpha value is $0.958>0.6$.

Table 9

Reliability Motivation Competence Test (X2)

\section{Reliability Statistics}

\begin{tabular}{ll} 
Cronbach's Alpha & N of Items \\
\hline 971 & 5
\end{tabular}

Source: SPSS 24 output, processed data

In the table 9 above the reliability test can be seen that the alpha cronbach value for the Motivation variable is 0.971 , this shows that the question of the Motivation variable is Reliable because the cronbach alpha value is $0.971>0.6$.

d. Reabilitas X3 (Curriculum)

Table 10

Reliability Curriulum Test (X3)

\begin{tabular}{ll}
\hline Reliability Statistics & N of Items \\
Cronbach's Alpha & 5
\end{tabular}

Source: SPSS 24 output, processed data

In the table 10 above the reliability test can be seen that the Cronbach alpha value for the Curriculum variable is 0.968 , this shows that the Curriculum variable question is Reliable because the Cronbach alpha value is as large as 0.968>0.6. 
"The Effect of Coach Competence, Participant Motivation and Curriculum On the Effectiveness of the Export Coaching Program"

d. Reliability Y (Effectiveness)

Table 11

Reabilility Effectivity Test (Y)

\section{Reliability Statistics}

\begin{tabular}{ll} 
Cronbach's Alpha & N of Items \\
\hline 966 & 5
\end{tabular}

Source: SPSS 24 output, processed data

In the table 11 above the reliability test can be seen that the Cronbach alpha value for the effectiveness variable is 0.966 , this shows that the question of the effectiveness variable is Reliable because the Cronbach alpha value is $0.966>0.6$.

\section{Classical Assumption Test Results}

Before testing with multiple regressions, the research variables were tested with classic assumptions including normality test, multicollinearity test, heteroscedasticity test, and autocorrelation test.

\section{Normality test}

Normality test is used to determine whether the regression model is normally distributed or not. Testing the normality of data in this study using the Kolmogrov-Smirnov Test technique. For calculations using the SPSS 24 for windows program. Normality test results for all variables can be seen in the following table:

Table 12

One Step Kolmogorov-Smirnov Test

One-Sample Kolmogorov-Smirnov Test

Unstandardized

Residual

\begin{tabular}{llr}
\hline N & & 40 \\
Normal Parameters, $\mathrm{b}$ & Mean &, 3723359 \\
& Std. Deviation &, 29686530 \\
Most Extreme Differences & Absolute &, 120 \\
& Positive &, 120 \\
& Negative & -110 \\
Test Statistic & &, 120 \\
Asymp. Sig. (2-tailed) & &, $149 \mathrm{c}$ \\
a. Test distribution is Normal. & & \\
b. Calculated from data. & & \\
c. Lilliefors Significance Correction. & & \\
\hline
\end{tabular}

Source: SPSS 24 output, processed data

From the results of the normality test of research variables it can be seen that all research variables have a significance value greater than 0.05 ( $p>0.05)$, so it can be concluded that all research variables are normally distributed. The table shows that the statistical test value for the unstandardized residual variable is 0.120 . Because the research variable has a probability value of 0.149 which is greater than 0.05 , all the variables in this study are normally distributed.

\section{Multicollinearity Test}

Multicollinearity test aims to test whether the regression model found a correlation between independent variables (independent). A good regression model should not occur correlation between independent variables (Multicollinearity does not occur). To find out 
whether multicollinearity occurs or not can be seen from the Toletance value and VIF value as shown in the table 13:

Table 13

Coefficient

\begin{tabular}{|c|c|c|c|c|c|c|c|}
\hline \multirow[b]{2}{*}{ Model } & \multicolumn{2}{|c|}{$\begin{array}{l}\text { Unstandardized } \\
\text { Coefficients }\end{array}$} & \multicolumn{3}{|c|}{$\begin{array}{l}\text { Standardized } \\
\text { Coefficients }\end{array}$} & \multicolumn{2}{|c|}{ Collinearity Statistics } \\
\hline & B & $\begin{array}{l}\text { Std. } \\
\text { Error }\end{array}$ & Beta & t & Sig. & Tolerance & VIF \\
\hline $1 \quad$ (Constant) & ,163 & 1,145 & & ,143 & ,887 & & \\
\hline Competence & 206 & ,077 & ,220 & 2,692 & 011 & ,384 & 2,606 \\
\hline Motivation & ,131 & ,108 & 130 & 1,208 & 235 & 219 & 4,560 \\
\hline Curriculum & ,656 & 129 & 654 & 5,074 & ,000 & 154 & 6,502 \\
\hline a. Dependent Var & le: Aff & & & & & & \\
\hline
\end{tabular}

Source: SPSS 24 output, processed data

Based on the table 13 above the Competence variable Tolerance value is $0.384>0.1$, tolerance value Motivation is $0.219>0.1$, Curriculum tolerance value is $0.154>0.1$. So there is no multicollinearity between the independent variables in the regression model. While the Competency VIF Value of $2.606<10$, the Motivation VIF value of $4.560<10$, the Curriculum VIF value of $6.502<10$. Therefore, it can be concluded that there is no multicollinearity between the independent variables in the regression model.

\section{Heteroscedasticity Test}

Heteroscedasticity test is carried out to test whether in the regression model there is an inequality of residual variance from one observation to another. As a result of the existence of heteroscedasticity in the regression results, the variance is no longer the minimum, testing of the regression coefficient becomes less strong, the estimation coefficient becomes biased and the conclusions drawn are wrong. How to detect the presence / absence of heteroscedasticity in the regression model with the Glejser test. Heteroscedasticity test results can be seen in the table below:

Table 14

Glejser test

\begin{tabular}{|c|c|c|c|c|c|c|}
\hline \multicolumn{7}{|c|}{ Coefficients } \\
\hline \multirow[b]{2}{*}{ Model } & & \multicolumn{2}{|c|}{$\begin{array}{l}\text { Unstandardized } \\
\text { Coefficients }\end{array}$} & \multirow{2}{*}{$\begin{array}{c}\text { Standardized } \\
\text { Coefficients } \\
\text { Beta }\end{array}$} & \multirow[b]{2}{*}{$\mathbf{t}$} & \multirow[b]{2}{*}{ Sig. } \\
\hline & & B & Std. Error & & & \\
\hline \multirow[t]{4}{*}{1} & (Constant) & 29,846 & 5,595 & & 5,334 & ,000 \\
\hline & competence &,- 035 & ,042 &,- 138 &,- 830 & ,412 \\
\hline & Motivation &,- 077 & 099 &,- 131 &,- 779 & ,441 \\
\hline & curriculum &,- 092 & 178 &,- 086 &,- 515 & 610 \\
\hline
\end{tabular}

Source: SPSS 24 output, processed data

Based on the table above, it can be seen that the significance value of the three independent variables are $0.412,0.441$ and 0.610 , respectively. The significance value of the competency, motivation and curriculum variables is greater than 0.05 . Thus it can be concluded that there is no heteroscedasticity problem in the regression model. So that among the independent variables occur variance homogeneity.

\section{Autocorrelation Test}

The autocorrelation test aims to test whether in a linear regression model there is a correlation between confounding errors in the t period and errors in the $\mathrm{t}-1$ period (previous). 
"The Effect of Coach Competence, Participant Motivation and Curriculum On the Effectiveness of the Export Coaching Program"

A good regression model is a regression that is free from autocorrelation. Aoutocorrelation test results can be seen from the results of Durbin - Watson.

Table 15

Durbin Watson Test

Durbin Watson Test

Model Summaryb

\begin{tabular}{|c|c|c|c|c|c|}
\hline Model & $\mathbf{R}$ & R Square & $\begin{array}{l}\text { Adjusted R } \\
\text { Square }\end{array}$ & $\begin{array}{l}\text { Std. Error of the } \\
\text { Estimate }\end{array}$ & Durbin-Watson \\
\hline 1 &, $182^{a}$ & ,033 &,- 048 & ,50782 & 1,978 \\
\hline
\end{tabular}

a. Predictors: (Constant), Curriculum, Competence, Motivation

b. Dependent Variable: electivity

Source: SPSS 24 output, processed data

Based on the table 15 above the Durbin-Watson value of 1.978, the Durbin-Waston value is compared to the table value using a significance value of $5 \%$ with a total of 3 independent variables and 1 dependent variable $(\mathrm{k}=3)$ with a total sample of $48(\mathrm{n}=48)$. The DurbinWaston magnitude for dL (outer boundary) $=1.3384$ and the Durbin-Waston magnitude table for $\mathrm{dU}$ (inner boundary) $=1.6589$. The value of $3-\mathrm{dL}(3-1.3384=1.6616)$ and the value of $3-$ $\mathrm{dU}(3-1.6589=1.3411)$.

Therefore, it can be concluded that Durbin-Waston 1.978 is greater than the upper limit (dU) 1.3411 and smaller than the outer limit (dL) 1.66616, it can be concluded that $\mathrm{HO}$ is accepted which states that there is no positive autocorrelation (see decision table) or it can be concluded there is no autocorrelation. Description of the decision table in the following table:

Table 16

Decision Durbin-Waston Autocorrelation Criteria

\begin{tabular}{|c|c|c|}
\hline Noll hypothesis & Decision & if \\
\hline No Positive Auto Correlations & Reject & $0<\mathrm{d}<\mathrm{dl}$ \\
\hline No Positive Auto Correlations & No Decision & $\mathrm{dl} \leq \mathrm{d} \leq \mathrm{du}$ \\
\hline No Negative Correlations & Reject & $4-\mathrm{dl}<\mathrm{d}<4$ \\
\hline No Negative Correlations & No Decision & $4-\mathrm{du} \leq \mathrm{d} \leq 4-\mathrm{dl}$ \\
\hline Positive or Negative & No Rejected & $\mathrm{du}<\mathrm{d}<4-\mathrm{du}$ \\
\hline Auto Correlation & & \\
\hline
\end{tabular}

Source: (Ghozali, 2016:108)

\section{Analysis of the Multiple Regression Model}

Multiple regressions are performed to determine the effect of independent variables on the dependent variable. The purpose of the multiple regression model analysis is to determine the estimated value of a variable (dependent variable) if the value of other variables related to it (other variables) has been determined. The results of multiple regressions can be seen in the following table17:

Table 17

Multiple Regression Result

\section{Coefficients $^{\mathrm{a}}$}

\begin{tabular}{llrrrrr}
\hline Model & \multicolumn{7}{c}{$\begin{array}{c}\text { Unstandardized } \\
\text { Coefficients }\end{array}$} & $\begin{array}{c}\text { Standardized } \\
\text { Coefficients } \\
\text { Beta }\end{array}$ & \multicolumn{1}{c}{ t } & Sig. \\
\hline 1 & B & 29,846 & 5,595 & & 5,334 &, 000 \\
& (Constant) &, 035 &, 042 &, 138 &, 830 &, 412 \\
& Competence &, 077 &, 099 &, 131 &, 779 &, 441 \\
& Motivation &, 092 &, 178 &, 086 &, 515 &, 610 \\
\hline
\end{tabular}

a. Dependent Variable: Affectivity

Source: SPSS 24 output, processed data 
Based on table 11, the coefficient value for the Competence variable is 0.035 , the Motivation variable is 0.077 , the Curriculum variable is 0.092 and the constant is 29.846. From these values, the regression equation is obtained as follows:

$$
\mathrm{Y}=\mathbf{2 9 , 8 4 6}+\text { 0,035 Competence }+ \text { 0,077 Motivation + 0,092 Curriculum }+e
$$

$$
\begin{aligned}
& \text { Where } \\
& Y=\text { Affectivity } \\
& X_{1}=\text { Competence } \\
& X_{2}=\text { Motivation } \\
& X_{3}=\text { Curriculum } \\
& e=\text { error }
\end{aligned}
$$

From the regression equation model we can get the following understanding:

1. Constant regression coefficient of 29,846 means that if the Competency, Motivation and Curriculum variables are considered constant (value 0), then the value of Performance Achievement will be $29.846 \%$.

2. Competency variable regression coefficient of 0.035 . This means that a positive relationship exists between Competence and Effectiveness. Which means that an increase in 1 unit of competency level will increase in effectiveness by $0.035 \%$.

3. Motivation variable regression coefficient of 0.077 This means that there is a positive relationship between motivation and effectiveness. Which means that an increase in 1 unit of motivation level will increase in effectiveness by $0.077 \%$.

4. Curriculum coefficient variable curriculum is 0.092 This means that there is a positive relationship between the curriculum of effectiveness. Which means that an increase in 1 unit of curriculum level will increase in effectiveness by $0.092 \%$.

5. Simple Linear Correlation Analysis

Person correlation analysis or also known as Product Moment Person correlation technique is an analysis to measure the closeness of the linear relationship between two variables that have a normal data distribution. The technique used is the Product Moment Person correlation technique. The results of the analysis can be seen in the table below:

Table 18

Correlation Results between Competency and Effectiveness

\begin{tabular}{llll}
\hline Correlations & & Competence & Affectivity \\
\hline Competence & Pearson Correlation & 1 &, $820^{* *}$ \\
& Sig. (2-tailed) & &, 000 \\
Affectivity & $\mathrm{N}$ & 40 & 40 \\
& Pearson Correlation &, $820^{* *}$ & 1 \\
& Sig. (2-tailed) &, 000 & \\
$* *$. Correlation is significant at the 0.01 level (2-tailed). & 40 & 40 \\
\hline
\end{tabular}

Source: SPSS 24 output, processed data

The table above shows the value of the correlation coefficient of 0.820 between Competence and Effectiveness, the value has a level of direct relationship according to the coefficient interval table between 0.80 - 1.00 which shows a very strong relationship. Significant in this study of 0,000 which is smaller than 0.05 based on the provisions, if the number is significant $<0.05$ then the relationship between the two variables is significant. 
Table 19

Motivation Correlation Results for Effectiveness

\section{Correlations}

\begin{tabular}{llll} 
& & Motivation & Affectivity \\
Motivation & Pearson Correlation & 1 &, $856^{* *}$ \\
& Sig. (2-tailed) & &, 000 \\
\multirow{4}{*}{ Affectivity } & N & 40 & 40 \\
& Pearson Correlation &, $856^{* *}$ & 1 \\
& Sig. (2-tailed) &, 000 & \\
& N & 40 & 40
\end{tabular}

**. Correlation is significant at the 0.01 level (2-tailed).

Source: SPSS 24 output, processed data

The table above shows that the value of the correlation coefficient of 0.856 between motivation to effectiveness, the value has a level of direct relationship according to the table of the coefficient interval between $0.80-1.00$ which shows a very strong relationship. Significant in this study of 0,000 which is smaller than 0.05 based on the provisions, if the number is significant $<0.05$ then the relationship between the two variables is significant.

Table 20

Curriculum Correlation Results for effectiveness

\begin{tabular}{llll}
\hline Correlations & & Curriculum & Affectivity \\
\hline Curriculum & Pearson Correlation & 1 &, $942^{* *}$ \\
& Sig. (2-tailed) &, 000 \\
Affectivity & $\mathrm{N}$ & 40 & 40 \\
& Pearson Correlation &, $942^{* *}$ & 1 \\
& Sig. (2-tailed) &, 000 & 40 \\
$* *$. Correlation is significant at the 0.01 level (2-tailed). & 40 & 40 \\
\hline
\end{tabular}

Source: SPSS 24 output, processed data

Based on Table 20 above, the correlation coefficient of 0.942 between the Curriculum to Effectiveness, the value has a level of direct relationship according to the table of the coefficient intervals between 0.80 - 1.00 which shows a very strong relationship. Significant in this study of 0,000 which is smaller than 0.05 based on the provisions, if the number is significant $<0.05$ then the relationship between the two variables is significant.

\section{Multiple Liner Correlation Analysis}

The correlation technique used is the Product Moment Person correlation technique to measure the strength of the relationship between two or more variables, the greater the value of $\mathrm{R}$, the stronger the relationship. The results of the analysis can be seen in table 4.14 below.

Table 21

Multiple Linear Correlation Result

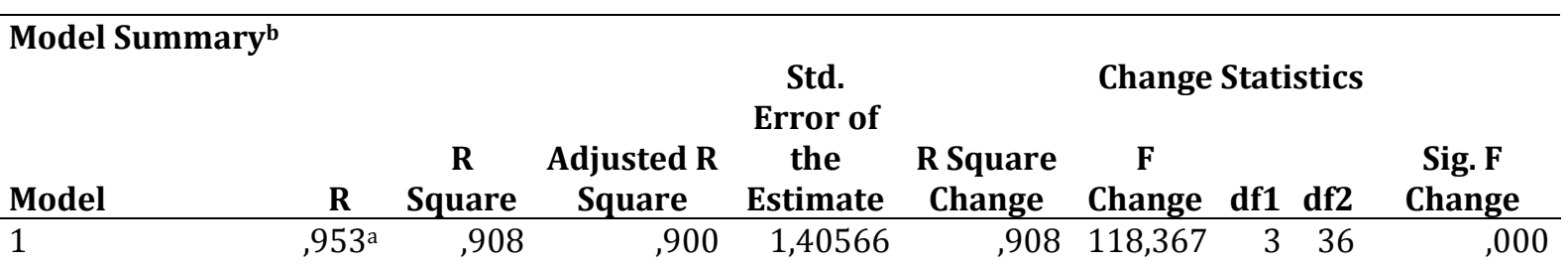

a. Predictors: (Constant), Curriculum, Competence, Motivation

b. Dependent Variable: Affectivity

Source: SPSS 24 output, processed data 
The table 21 above shows the value of the correlation coefficient of 0.953 between the variables Competency, Motivation, Curriculum and Effectiveness of these values have a direct relationship level according to the coefficient interval between $0.80-1.00$ which shows a very strong relationship. And Significant in this study amounted to 0,000 which is smaller than 0.05 . Based on the provisions, if the number is significant $<0.05$ then the relationship between the four variables is significant.

\section{Determination coefficient}

The coefficient of determination is a measure that shows how much variation in the data can be explained by the regression model that is built. Adjusted R Square Value. The coefficient of determination (KD) essentially provides an interpretation of the effect of two variables, which are the square of the correlation coefficient. In this case the coefficient of determination is used to find out what percentage of Competence, Motivation and Curriculum on Effectiveness. The results of the analysis can be seen in the table below

Table 22

Determination Coefficient Test Results

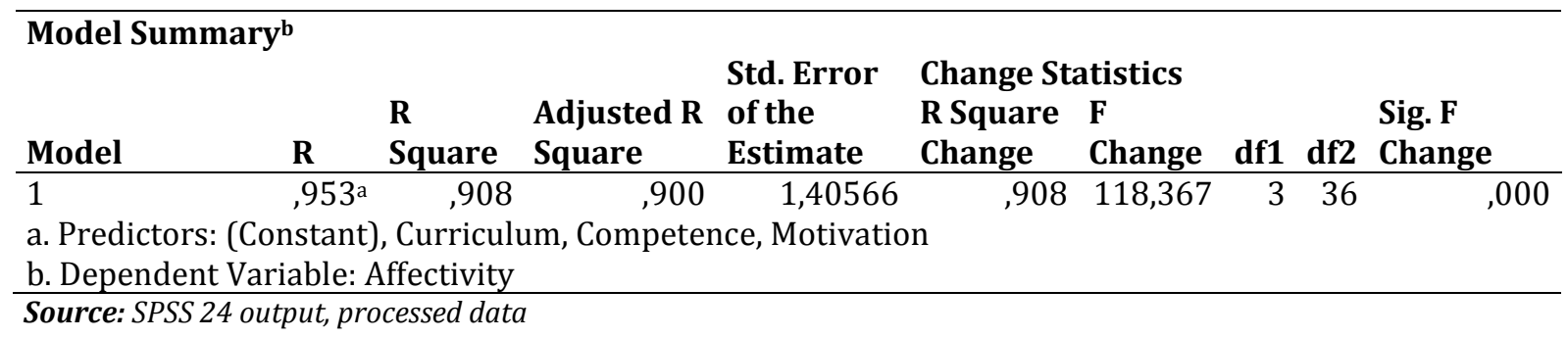

Based on the table 22 above, the result of the coefficient of determination of the Adjusted $\mathrm{R}$ Square value is 0.900, which means the Competency, Motivation and Curriculum variables can explain the Effectiveness variable by $90 \%$, so it can be concluded that Competency, Motivation and Curriculum affect Effectiveness. The remaining 10\% possibility is explained by other factors outside the model.

\section{T test (Test partially / individually)}

Hypothesis test results can be seen from the level of significance obtained from the results of data processing using the help of the SPSS 24 program. Hypothesis $t$ test or individual test (partial) between the independent variables Competency, Motivation and Curriculum to the dependent variable, Effectiveness. Partial testing is carried out to find out one by one, the presence or absence of the influence of independent variables in the form of Competency, Motivation and Curriculum variables on the Effectiveness variable.

$\mathrm{T}$ test is done by comparing the $\mathrm{t}$-count value with the $\mathrm{t}$-table. If tcount is greater than ttable then $\mathrm{HO}$ is rejected $\mathrm{Ha}$ is accepted, meaning that the independent variable has a significant effect on the dependent variable. Conversely, if the tcount is smaller than the table then $\mathrm{HO}$ is accepted $\mathrm{Ha}$ is rejected, meaning that the independent variable does not have a significant effect on the dependent variable.

Based on the table 23 above, a tcount of 8.832 was obtained and a significance value of 0.000 was compared using a Significant level of $0.05(5 \%)$. With degrees of freedom (with a value of $\alpha=0.05 \mathrm{dk}=40-1=39$ ) a table of 1.68385 was obtained, it turns out that tcount $>t$ table, 8.832> 1.68385 then $\mathrm{H} 0$ was rejected and Ha was accepted. Based on these results it can be concluded that there is a significant positive effect between the Competency variable and the Effectiveness variable. The results of the partial t test test analysis can be seen as in the following table: 
"The Effect of Coach Competence, Participant Motivation and Curriculum On the Effectiveness of the Export Coaching Program"

Table 23

T test results Competency for Effectiveness

Coefficients $^{\mathrm{a}}$

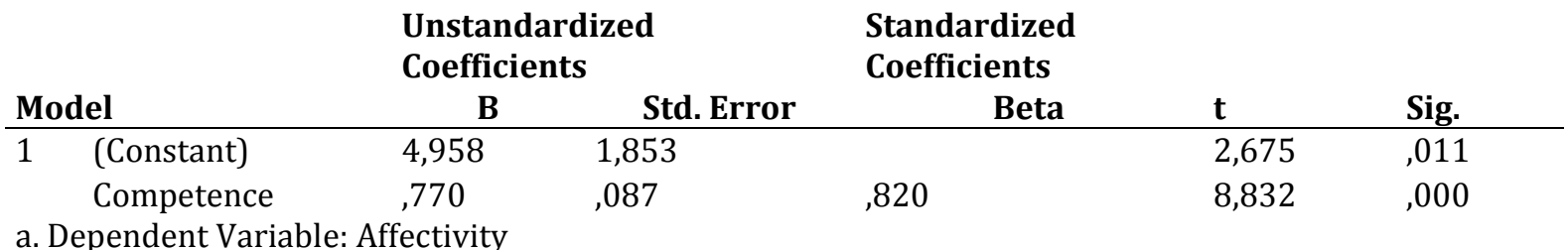

Source: SPSS 24 output, processed data

Based on the table 24 above, a tcount of 10.186 was obtained and a significance value of 0.000 was compared using a Significant level of $0.05(5 \%)$. With the degree of freedom (with a value of $\alpha=0.05 \mathrm{dk}=40-1=39$ ) obtained a table 1.68385, it turns out tcount $>\mathrm{t}$ table, 10.186> 1.68385 then $\mathrm{HO}$ is rejected and $\mathrm{Ha}$ is accepted. Based on these results it can be concluded that there is a significant positive influence between the Motivation variable and the Effectiveness variable.

Table 24

T test results Motivation for Effectiveness

\begin{tabular}{|c|c|c|c|c|c|c|}
\hline \multicolumn{7}{|c|}{ Coefficients $^{a}$} \\
\hline \multirow{2}{*}{\multicolumn{2}{|c|}{ Model }} & \multicolumn{2}{|c|}{$\begin{array}{l}\text { Unstandardized } \\
\text { Coefficients }\end{array}$} & \multirow{2}{*}{$\begin{array}{c}\text { Standardized } \\
\text { Coefficients } \\
\text { Beta }\end{array}$} & \multirow[b]{2}{*}{$\mathbf{t}$} & \multirow[b]{2}{*}{ Sig. } \\
\hline & & B & Std. Error & & & \\
\hline 1 & (Constant) & 3,056 & 1,793 & & 1,705 & ,096 \\
\hline & $\begin{array}{l}\text { Motivation } \\
\text { ndent Varial }\end{array}$ & ,859 & ,084 & ,856 & 10,186 & 000 \\
\hline
\end{tabular}

Source: SPSS 24 output, processed data

Based on table 25 above, a tcount of 17.252 was obtained and a significance value of 0.000 was compared using a significant level of $0.05(5 \%)$. With the degree of freedom (with a value of $\alpha=0.05 \mathrm{dk}=40-1=39$ ) obtained a table 1.68385, it turns out tcount $>\mathrm{t}$ table, 17.252>1.68385 then $\mathrm{HO}$ is rejected and Ha is accepted. Based on these results it can be concluded that there is a significant positive effect between the Curriculum variable and the Effectiveness variable.

Table 25

Curriculum $\mathbf{t}$ test results on Effectiveness

\section{Coefficients}

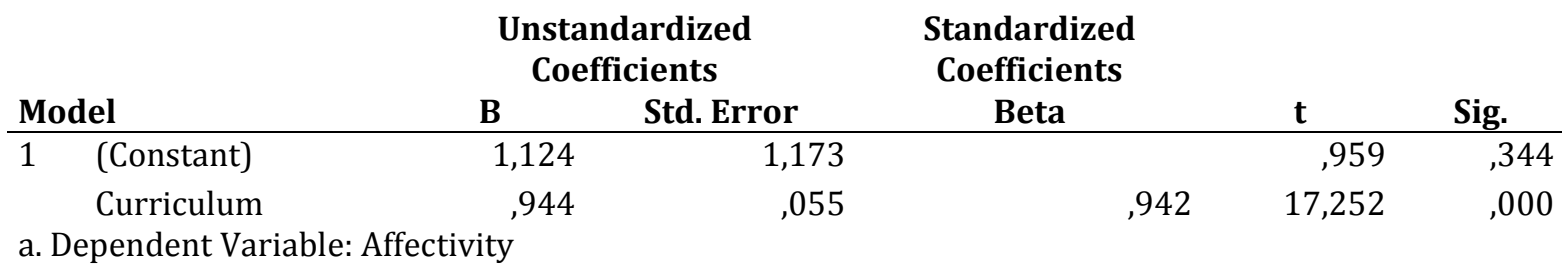

Source: SPSS 24 output, processed data

F Test (Simultaneous Test)

Simultaneous testing is intended to test the presence or absence of the influence of all the independent variables in this study, or together with the dependent variable, an analysis is done with the $\mathrm{F}$ (annova) test by comparing the $\mathrm{F}$ table with Fcount. The significance level is 5\%, where if Fcount $>$ Ftable, then Ha is accepted and HO is rejected. Conversely, if Fcount <Ftable, then $\mathrm{Ha}$ is rejected and $\mathrm{HO}$ is accepted. If the significance value is smaller than 0.05 and Fcount> 
Ftable, it shows that simultaneously the Competency, Motivation and Curriculum variables influence the Effectiveness. The results of simultaneous hypothesis testing can be seen in the following table:

Table 26

Results F Test

\section{ANOVA ${ }^{\mathrm{a}}$}

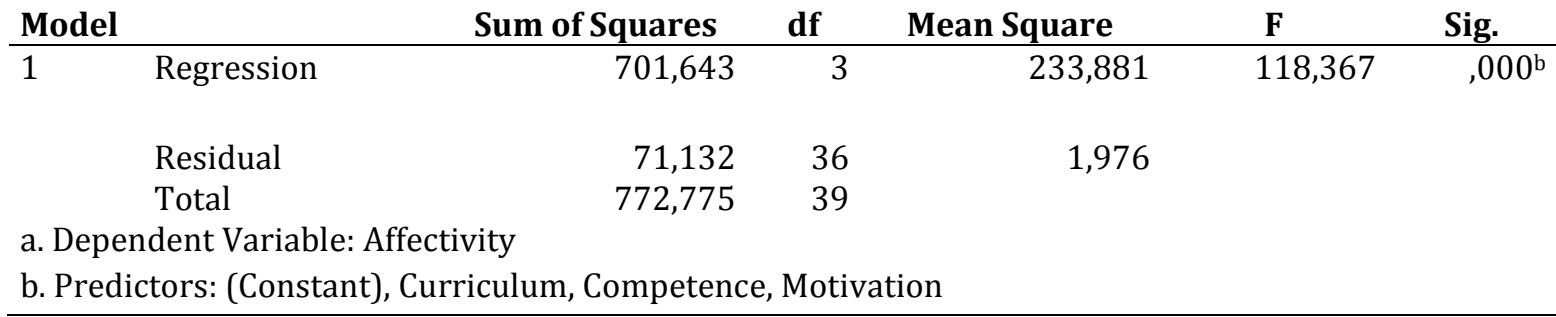

Source: SPSS 24 output, processed data

Based on table 26 the Fcount result in the ANOVA table is 118.376 greater than the value of Ftable $2.87(\mathrm{dk}=40-3-1=36)$, Fcount $>$ Ftable is $118.376>2.87$ then Ha is accepted and $\mathrm{H} 0$ is rejected which means the independent variable is independently simultaneously affect the dependent variable. $F$ test results show that the significant $F$ value of 0,000 is smaller than the significance level of $0.05(5 \%)$, it can be concluded that the hypothesis is accepted. This means that there is a positive and significant effect simultaneously between Competence, Motivation and Curriculum on Effectiveness.

\section{E. Discussion}

The Export Coaching Program implemented by the Export Education and Training Center, Ministry of Trade, has been running since 2010, with 3 batches per year for three different regions. The results achieved from the implementation of the program over the past 5 years are as shown in the following table.

Table 27

Achievement of the Export Assistance Program Indonesian Export Training Center 2004-2018

\begin{tabular}{ccccccc}
\hline Year & Batch's & $\begin{array}{c}\text { Total } \\
\text { Participants }\end{array}$ & $\begin{array}{c}\text { New } \\
\text { Exporters }\end{array}$ & $\begin{array}{c}\text { Objectives } \\
\text { Of New } \\
\text { Exporters }\end{array}$ & $\begin{array}{c}\text { Achievements } \\
\text { Based On } \\
\text { Objectives }\end{array}$ & $\begin{array}{c}\text { Achievements } \\
\text { Based On Total } \\
\text { Participants }\end{array}$ \\
\hline 2014 & 4 & 120 & 22 & 20 & $110 \%$ & $18 \%$ \\
2015 & 3 & 90 & 22 & 22 & $100 \%$ & $24,55 \%$ \\
2016 & 3 & 90 & 25 & 25 & $100 \%$ & $27,78 \%$ \\
2017 & 3 & 90 & 28 & 28 & $100 \%$ & $37,33 \%$ \\
2018 & 3 & 75 & 32 & 32 & $100 \%$ & $42,67 \%$ \\
Total & 16 & 465 & 129 & 127 & $101,57 \%$ & $27,74 \%$ \\
\hline
\end{tabular}

Sources: Indonesian Export Training Center (IETC, 2019)

In the table 27 there are columns for the number of participants and the target column for new exporters. The target to be achieved is not the same as the number of participants. This means that not all participants are expected to become new exporters, due to various considerations such as: 1) Not all export and import policies are within the scope of the Ministry of Trade's authority, but also in other ministries, so it is not easy to produce new exporters only from programs implemented by Ministry of Trade; 2) Not all participants have the capacity as exporters, because many of them do not yet have complete business legality and thus do not meet the requirements as an exporter; 3) The occurrence of export transactions cannot be ensured within a certain period of time can be obtained. 4) UKM is a business actor who doubles all the activities of the company, often the participants find it difficult to divide their time between joining the program and running their business at the same time. This affects the level 
of their presence in the activities of the Export Coaching Program. Because of these considerations, the target for new exporters is not as large as the number of participants in each batch.

Curriculum of The Export Coaching Program since 2010 has improved several times. During the revision period last year, the new curriculum program was completed 4 times. In the first year of the implementation program, the Canadian Trade Facilitation Organization (TFO) as IETC's collaborative partner in implementing the Export Coaching Program provides this program for 3 people who must be supported by participants for one year, figure 2 as follows:

\begin{tabular}{|c|c|c|}
\hline Level 1 & Level 2 & Level 3 \\
\hline $\begin{array}{l}\text { Business } \\
\text { Readiness }\end{array}$ & $\begin{array}{c}\text { Market } \\
\text { Development }\end{array}$ & $\begin{array}{c}\text { Market } \\
\text { Entry }\end{array}$ \\
\hline $\begin{array}{l}\text { - Developing a Vision } \\
\text { - SWOT Analysis } \\
\text { - Ready to export? } \\
\text { - Building Confidence } \\
\text { - International } \\
\text { Business Plan }\end{array}$ & $\begin{array}{l}\text { - Market Research } \\
\text { - Marketing } \\
\text { Strategy } \\
\text { - Promotional } \\
\text { Materials } \\
\text { - Costing and } \\
\text { Pricing } \\
\text { - Financingand } \\
\text { Getting Paid }\end{array}$ & $\begin{array}{l}\text { - Entry Strategy } \\
\text { - Partnering } \\
\text { - Documentation } \\
\text { - Packaging and } \\
\text { Labelling } \\
\text { - Transportation } \\
\text { and Logistics }\end{array}$ \\
\hline
\end{tabular}

Figure2

Export Competence Area

Then the three stages are translated into a series of activities from figure 3 as follows:

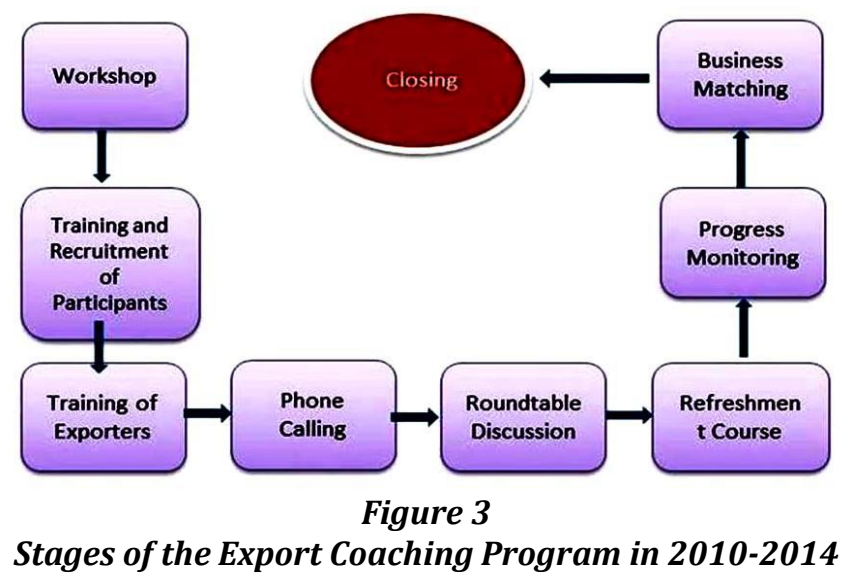

From the series of activities above, there are mentoring activities namely phoned calling, progress monitoring and business matching. In this activity the coach provides guidance and counseling on the problems faced by participants while undergoing activities in the Export Leading Program. This counseling is a technique or service in guidance, which is flexible or flexible and comprehensive, through which counseling is expected to occur fundamental changes from the participants, including attitudes, actions, thoughts, views and feelings.

In 2015, the curriculum of the Export Coaching Program was evaluated and perfected, so that the form would be as follows: 


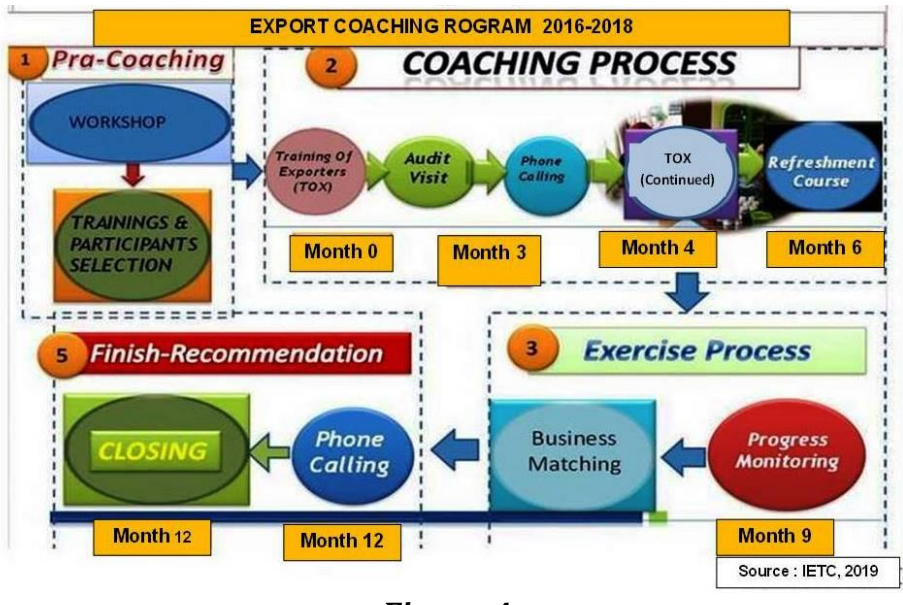

Figure 4

Step to Export Coaching Program 2016-2018

In accordance with this curriculum, the implementation of the Export Coaching Program for 12 months is classified into 3 stages, namely 1) Pre Coaching which consists of Workshop and participant selection; 2) Coaching Process, which consists of Training of Exporters, Audit Visit, phone calling, Advanced TOX and Refreshment Course. The third stage is the exercise process, namely Progress monitoring and Business Matching. The final stage is FinishRecommendation, which consists of Phone Calling and Closing. In the Closing Event a grading system was introduced, namely the classification of participant performance after attending the Export Assistance Program.

In 2018, the curriculum will be further refined by adding two new activities, namely Product Development and Market Development. This activity is a sharpening of the phone calling and audit visit activities, so that it no longer only asks the progress of the participants, but also assesses readiness by visiting the company location. To be more selective in accepting participants, at the beginning of the implementation in addition to conducting workshops to recruit potential participants, verification of the feasibility of SMEs was also carried out by conducting site visits to company locations. Thus, in the implementation of the Export Coaching Program in 2018, participants will be visited 4 times, namely verification, product assistance, market assistance and Progress Monitoring.

\section{CONCLUSION}

The Export Coaching Program for potential SMEs carried out in a full year is a flagship program from the Indonesian Export Education and Training Center (IETC). Through this Export Mentoring Program, a number of participants can successfully become new exporters, according to the target set. The results showed that the three variables, namely coach competency, participant motivation and curriculum have a strong relationship with the effectiveness variable. It is known that curriculum variables show the most significant influence on the effectiveness of this program. Since it began to be implemented in 2010 the Export Coaching Program curriculum has undergone 4 refinements. In the 2018 implementation, the new curriculum that has been refined 2 times but the final results obtained have not shown a significant increase. Based on the use of the new curriculum, there was only an increase of $1414 \%$, which ranged from 3 to 4 people, although this was in accordance with the targets set by IETC. When seen from the total number of participants, in 2018 there was only an effectiveness achievement of $43 \%$.

In accordance with the research findings which state that the variables of coach competency, participant motivation and curriculum have a strong correlation with the effectiveness of the Export Assistance Program, these three factors need to receive greater attention and continue to improve in quality. Considering that a significant increase in the number of new exporters has not yet been reached, it can be assumed that in addition to the curriculum and the two other variables that have been studied, there are still other factors that also have an effect, so this 
research needs to be followed by further research using other factors, both as independent variables and dependent variables.

\section{REFERENCE}

Ani Solihat, Iis Iskandar, Andry Trijumansyah,Eli Susana dan Nela Widyastuti. Jurnal Pengabdian Kepada Masyarakat Vol. 1 No. 3 Agustus 2018.

Beahm,G. Belajar dari Life by Design, Pidato Steve Jobs paling terkenal sepanjang Masa, Hak Cipta dan Terjemahan Indonesuia @2014 Penerbit Gramedia Pustaka Utama.

Dewanto, Wawan, dkk, Internasionalisasi UKM, Usaha Kecil dan Mikro Menuju Pasar Global, Penerbit ANDI, Yogyakarta, 2019.

Endang Dhamayantie(1) Rizky Fauzan, Penguatan Krakteristik dan Competence Kewirausahan Untuk Meningkatkan Kinerja UMKM, Jurnal Manajemen, Strategi Bisnis dan Kewirausahaan Vol. 11, No. 1, Februari 2017.

Fenti Hikmawati, Dr, MSi, Bimbingan dan Konseling, Edisi Revisi, Penerbit RajaGrafindo Persada, Jakarta, 2016.

Ghozali, Imam, Prof. Drs, M. Com., Ph.D., CA., Akt. Desain Penelitian Kuantitatif \& Kualitatif, Untuk Akuntansi Bisnis,Dan Ilmu Sosial Lainnya, Penerbit: Yoga Pratama ( Fakultas Ekonomika Dan Bisnis UNDIP Semarang ), Tahun Terbit: 2016.

Gomulya, Brnny, Hyacintha Susanti \& Heria Windasuri, Coaching Practises, Menginspirasi, Menunbuhkan dan Meningkatkan Performa Tim, Penerbit Gramedia Pustaka Utama, 2019.

Gujarati D, Dasar-Dasar Ekonometrika (Kelima), Penerbit Salemba 4, Jakarta 2015.

Gunawan Arif, Duh, RI Jauh Tertinggal di Indeks Inovasi Global 2019 NEWS - Arif, CNBC Indonesia, 25 July 2019.

Ika Maryani, Mustofa Ahda, Septian Emma dan Dwi Jatmika. Affectivity Pendampingan Kelompok Dalam Meningkatkan Motivation Berwirausaha Peternak Sapi Perah. Jurnal Pengabdian dan Pemberdayaan Masyarakat ISSN: 2549-8347 (Online), ISNN: 2579-9126 (Print) Volume 2 No. 1 Maret 2018.

Jean Côté and Wade Gilbert, An Integrative Definition of Coaching Effectiveness and Expertise, International Journal of Sports Science \& Coaching Volume $4 \cdot$ Number $3 \cdot 2009$.

Jones, R. J., Woods, S. A. and Guillaume, Y. R. F. (2015), The effectiveness of workplace coaching: a meta-analysis of learning and performance outcomes from coaching Journal of Occupational and Organizational Psychology.

Julia, Erni KOK, Coaching Genius, Karir Sukses Luar Biasa Hidup Semakin Bahagia, Penerbit PT Gramedia Pustaka Utama, Jakarta, 2015.

Nana Sudjana. Dasar-Dasar Proses Belajar Mengajar., Sinar Baru Algesindo. Bandung, 2005.

Nanny Rodjinandari, Bambang Supriadi, Competence Pendampingan Pemandu Wisata Lokal Sebagai Developer of People. Program Diploma Kepariwisataan Universitas Merdeka Malang1 Jl. Bandung No. 1 Malang. Jurnal PESONA ISSN Vol. 2 No. 01 Desember 2016.

Ninuk Purwaningsih, Titi Mawasti dan Yudhistira Saraswati, Analisis Kebutuhan Pendampingan dan Competence Pendamping Pelaku Usaha Industri Jamu, Jurnal Jamu Indonesia, 2017.

Norasmah Othman --- Swee Yee Chia, Coaching in Action Research 1,2Faculty of Education Universiti Kebangsaan Malaysia, Bangi, Selangor, Malaysia, Journal of Empirical Studies 2014 Vol. 1, No. 3, pp. 98-104 ISSN(e): 2312-6248 ISSN(p): 2312-623X (C) 2014 Conscientia Beam.

Novfitri Landong dan Namora Sihombing S.sos.M.si, Model Pendampingan UKM di Kota Tangerang Selatan, Penerbit PKN STAN Press. (C) 2018.

Robert Witherspoon dan Randall P. White, Executive Coaching A Continuum of Roles, Consulting Psychology Journal: Practice and Research Spring 1996 (1996).

Sugiyono. Metode Penelitian: Kuantitatif, Kualitatif dan R\&D, Penerbit Alfabeta, Bandung, 2017.

TFO Canada, IETC Coaching System, A Training and Coaching Program For Indonesian Exporters, Presentation of June 7th, 2010.

UU No. 20 Tahun 2003 tentang Sistem Pendidikan Nasional. 
"The Effect of Coach Competence, Participant Motivation and Curriculum On the Effectiveness of the Export Coaching Program"

Yeni Priatna Sari, Model Pendampingan UMKM Pengolahan Hasil Laut Dengan Metode Pendekatan Pendampingan Terintegrasi, Jurnal MONEX Volume 8 Nomor. 1 Januari 2019 